\title{
Nilai Moral Bagi Kalangan Muda Dalam Mempergunakan Internet
}

\author{
Irma Rahmi Oktaviani', Muhamad Abil Fachrizal' ${ }^{2}$, Ayang Nurmelisa Putri ${ }^{3}$, Mochamad Dimas \\ Nurhaadiiansyah ${ }^{4}$ \\ 1,2,3,4Prodi IImu Komunikasi, Fakultas IImu Komunikasi, Universitas Islam Nusantara Bandung
}

\begin{tabular}{|c|c|}
\hline ARTICLE INFO & ABSTRACT \\
\hline Article history: & \multirow{4}{*}{$\begin{array}{l}\text { Internet makes it easy for people, especially young people to } \\
\text { communicate. Advances in Internet technology and mobile phones, } \\
\text { social media is also growing rapidly. Young people in the modern era } \\
\text { are proficient in managing and utilizing computer technology in using } \\
\text { the Internet. The modern era can be said to be an era where there is a } \\
\text { lot of development, be it the development of culture, the development } \\
\text { of education and technology. It is very regrettable if the use of the } \\
\text { internet even make the younger generation has no moral value in itself. } \\
\text { Therefore, in order that moral values are always used young people to } \\
\text { use the internet there are some that can be considered and applied ie, } \\
\text { embedding religious values, raise the awareness of young people and } \\
\text { the role and improve discipline. }\end{array}$} \\
\hline $\begin{array}{r}\text { Received Sep 03, } 2021 \\
\text { Revised Sep 22, } 2021 \\
\text { Accepted Okt 30, } 2021\end{array}$ & \\
\hline \multirow{5}{*}{$\begin{array}{r}\text { Keywords: } \\
\text { Moral Values; } \\
\text { Young People; } \\
\text { Using the Internet. }\end{array}$} & \\
\hline & \\
\hline & ABSTRAK \\
\hline & $\begin{array}{l}\text { Internet memudahkan semua kalangan terutama kalangan muda untuk } \\
\text { melakukan komunikasi. Dengan kemajuan teknologi internet dan } \\
\text { telepon seluler, media sosial juga berkembang pesat. Anak muda di } \\
\text { era modern mahir dalam mengelola dan mempergunakan teknologi } \\
\text { komputer dalam penggunaan Internet. Era modern bisa dikatakan } \\
\text { sebagai era dimana marak sekali yang namanya perkembangan, baik } \\
\text { itu perkembangan kebudayaan, perkembangan pendidikan maupun } \\
\text { teknologi. Maka sangat di sayangkan apabila penggunaan internet } \\
\text { malah membuat generasi muda tidak memiliki nilai moral dalam } \\
\text { dirinya. Maka dari itu, agar nilai moral senantiasa digunakan anak } \\
\text { muda dalam menggunakan interniet ada beberapa yang bisa } \\
\text { diperhatikan dan diterapkan yakni, Menanamkan nilai-nilai agama, } \\
\text { Meningkatkan kesadaran anak muda, dan Peran meningkatkan } \\
\text { kedisiplinan. }\end{array}$ \\
\hline & This is an open access article under the $C C B Y-N C$ license. \\
\hline \multicolumn{2}{|l|}{ Corresponding Author: } \\
\hline \multicolumn{2}{|c|}{$\begin{array}{l}\text { Irma Rahmi Oktaviani } \\
\text { Prodi Ilmu Komunikasi Fakultas Ilmu Komunikasi, } \\
\text { Universitas Islam Nusantara Bandung, } \\
\text { Jl. Soekarno-Hatta No.530, Sekejati, Kota Bandung, Jawa Barat } 40286 \\
\text { Email : Irmarahmioktvn20@gmail.com }\end{array}$} \\
\hline
\end{tabular}

\section{PENDAHULUAN}

Internet adalah jaringan komputer yang menyediakan fungsi ekonomi bagi perusahaan, dapat digunakan sebagai alat pemasaran atau publikasi perusahaan, atau sebagai alat komunikasi. Internet juga dapat dianggap sebagai jaringan komputer global, yang bertukar data melalui sistem jaringan publik. Pada era globalisasi ini, sangat banyak anak muda dimulai dari SD, SMP, SMA dan Perguruan Tinggi sudah tidak asing lagi dengan yang namanya Internet, bahkan sampai kalangan orang tuapun pada zaman ini banyak yang menggunakan Internet, dengan adanya kemajuan internet sudah menjadi bagian yang tidak bisa terpisahkan bagi masyarakat dan khususnya bagi kalangan anak muda di Indonesia. 
Perkembangan Internet secara drastis terjadi selama satu dekade, dari awal 1980-an hingga awal 1990-an. Antara 1981 dan 1989, jumlah komputer yang terkoneksi dengan Internet meningkat dari 300 ke 90.000 . Pertumbuhan ini sebagian besar didukung oleh adopsi konsumen pada komputer pribadi dan juga melalui kooperasi dan kolaborasi antara universitas dan badan penelitian dalam pengembangan perintah yang distandarkan dan perkembangan perangkat lunak (Hartley, 2010).

Dengan adanya Internet sangat memudahkan bagi semua kalangan terutama kalangan muda untuk melakukan komunikasi kepada seseorang. Internet pun menyediakan fasilitas seperti facebook, tweeter, whatsapp, Instagram, google clashroom, zoom, google meet, dan youtube sebagai bahan untuk mencari suatu informasi-informasi dengan sangat mudah terutama bagi masyarakat dan kalangan muda saat ini. anak muda saat ini juga kerap mahir dalam mengelola dan mempergunakan teknologi komputer dalam mempergunakan Internet. Memanfaatkan komputer sebagai alat bantu pengolahan data dengan membangun sistem pengolahan data terkomputerisasi, baik untuk keperluan pribadi maupun organisasi. (Nurbaiti et, al 2020).

Pada dasarnya manusia adalah manusia sosial, karena tidak ada yang bisa hidup sendiri tanpa berdekatan atau dengan orang lain, manusia akan saling membutuhkan, dan setiap orang sekarang pasti memiliki karakteristik yang berbeda-beda, dan keunikannya adalah apa adanya. Di era globalisasi khususnya di bawah perkembangan yang sangat pesat, perubahan telah terjadi. Internet merupakan salah satu hasil kesempurnaan dan kemajuan ilmu pengetahuan dan teknologi yang diciptakan oleh tangan manusia. Dengan kemajuan teknologi internet dan telepon seluler, media sosial juga berkembang pesat. Hanya dengan ponsel, Anda dapat membuat jejaring sosial kapan saja, di mana saja.

Sebagaimana Fredik Melkias Boiliu (2020) berpendapat bahwa kecepatan seseorang dapat mengakses media sosial mengakibatkan terjadinya fenomena besar terhadap arus informasi tidak hanya di negara negara maju, tetapi juga di Indonesia. Era digital memberikan kemudahan, kenyamanan, dan kesenangan bagi manusia, memudahkan manusia untuk saling berkomunikasi. Namun, dengan adanya kemajuan itu juga memberikan dampak buruk akan kepekaan moral. Terlihat ada beberapa kesenjangan moral di lingkungan sekitar karena kurangnya perilaku pembiasaan mengenai moral, akhlak maupun karakter. (Nurfitriana, ika 2021)

Adapun Karlita (2013) mencontohkan, lima tahun lalu, Indonesia termasuk dalam sepuluh besar negara yang mengunjungi situs porno di dunia maya, menurut Kementerian Komunikasi dan Informatika, peringkat ini setiap tahun naik. Anehnya, ada anak di bawah umur di antara mereka yang mengunjungi situs porno. Dikutip dari kompas.com Sebanyak 101 anak yang putus sekolah dan ikut serta dalam tawuran dan kenakalan remaja lainnya di Surabaya, Jawa Timur, diundang untuk memberikan komentar. Kasus tersebut terjadi karena pengaruh jejaring sosial (Basyari, 2019).

Bangsa Indonesia merupakan bangsa yang sangat menjunjung tinggi nilai-nilai moral Pancasila. Nilai-nilai moral tersebut meliputi seluruh aspek kehidupan manusia sebagai bangsa dan negara. Nilai-nilai moral tersebut merupakan nilai-nilai yang mengatur ketuhanan, kemanusiaan, persatuan bangsa, demokrasi, dan keadilan, namun seiring berjalannya waktu, terutama dengan kemajuan teknologi, seolah-olah menggerogoti nilai-nilai moral suatu bangsa, terutama generasi muda. Setelah remaja mengenal internet bergabung dengan situs yang ada di internet seperti Facebook dan situs lainnya, seperti game online yang membuat remaja betah di depan komputer maupun gadget bahkan terkadang bergadang sampai larut malam sehingga remaja cenderung menjadi malas dalam hal belajar. Tanpa pengawasan dari orang tua remaja dengan mudah mengakses foto atau vidio dewasa hal ini jika tidak di cegah tentu dapat memicu hal-hal negatif yang tidak di inginkan tidak bisa di pungkiri kita hidup bermasyarakat dengan kemajemukan sifat dan perilaku. Hal ini tidak mungkin bagi kita untuk mengubah perilaku setiap individu menjadi sesuai dengan keinginan atau baik menurut penilaian kita, belum tentu juga baik bagi orang lain. 
Era modern juga bisa dikatakan sebagai era dimana marak sekali yang namanya perkembangan, baik itu perkembangan kebudayaan, perkembangan pendidikan maupun teknologi. Akan sangat di sayangkan apabila adanya era global ini malah membuat generasi mudanya tidak memiliki nilai moral dalam dirinya. Pendapat Zuria (2007) mengatakan bahwa moralitas adalah sesuatu yang membatasi, artinya tidak hanya terlihat baik, tetapi juga membimbing perilaku dan pemikiran seseorang ke arah yang baik. Moralitas didasarkan pada disiplin. Realisasi moral yang tidak disiplin identik dengan imoralitas.

Untuk dapat membentuk karakter baik tentunya perlu dipersiapakan sejak sedini mungkin karena masa usia dini merupakan masa keemasan, pada masa ini anak akan menyerap apa saja yang diberikan kepadanya entah itu dari perkataan dan perbuatan orang tua atau dari lingkungannya. Bangsa Indonesia sangat menjunjung tinggi nilai agama dan moral. Nilai luhur inipun dikehendaki menjadi motivasi spiritual bagi bangsa ini dalam rangka melaksanakan sila-sila lainya dalam Pancasila. (Siti Nurjanah 2018). Perubahan teknologi komunikasi yang sangat cepat dan pesat dari tahun ke tahun dapat mempengaruhi cara berpikir seorang remaja dan mempengaruhi interaksi sosial mereka. Perubahan teknologi komunikasi ini dapat mempunyai dampak positif dan negatif bagi seorang remaja. Apalagi masa remaja adalah masa transisi yang sedang mencari jati diri.

Tanpa adanya bimbingan, dan pengawasan dari keluarga ataupun orang-orang terdekat, teknologi komunikasi dapat dimanfaatkan untuk melakukan perbuatan yang negatif, yang melanggar nilai dan norma yang berlaku dalam masyarakat. (Ana puji astuti 2014). Sebagaimana Santrook (2012) menjelaskan masa remaja juga merupakan masa berpikir kritis. Dimana perubahan kognitif yang memungkinkan peningkatan berpikir kritis di masa remaja mencakup: (1) Meningkatnya kecepatan, otomatisasi, dan kapasitas dalam memroses informasi, yang memungkinkan penggunaan informasi yang diperoleh untuk dimanfaatkan bagi tujuan-tujuan lain; (2) isi pengetahuan yang lebih luas di berbagai bidang; (3) meningkatnya kemampuan untuk mengkonstruksikan kombinasi baru dari pengetahuan; dan (4) penggunaan strategi atau prosedur secara lebih luas dan spontan dalam mengaplikasikan atau memperoleh pengetahuan, seperti perencanaan, mempertimbangkan berbagai alternatif, dan pengawasan kognitif.

Pada dasarnya jika moral sudah terbentuk melalui proses dasar yaitu imitasi maka hal itu akan menjadi kebiasaan dalam kehidupan sehari hari. Jika perilaku amoral atau perilaku buruk yang sudah didapatkan anak sejak dini yang mana pada masa itu anak belum bisa membedakan mana hal yang baik dan buruk, maka pada saat anak menjadi dewasa ia tidak akan benar-benar memahami akan perilaku yang benar dan perilaku yang salah (Arini Ainun Ridho 2020). Berdasarkan observasi yang terihat dilapangan terdapat perilaku tidak wajar oleh remaja yang mana peneliti maksud yaitu remaja bermain internet secara berlebihan sehingga dapat melalaikan kewajiban seperti sholat dan kurangnya waktu belajar hal ini di karnakan sudah keasyikan berinternet seperti instagram, youtube, game online, dan lain sebagainya. Namun dikhawartirkan jika internet telah disalahgunakan dan kurangnya pengawasan dari orang tuanya sehingga remaja semakin merajalela untuk berinternet.

Namun, pada kenyataannya dilapangan sedikit sekali remaja yang mendapat pengawasan dalam penggunaan internet ini. Remaja dianggap sudah bisa memilih yang baik benar sehingga sebagian orang tua memberikan kebebasan dalam hal ini, karena selain manfaat yang beragam seperti yang dijabarkan diatas internet adalah marabahaya yang dapat menyebabkan malapetaka bagi penggunanya, seperti kebanyakan kasus yang terjadi pada saat sekarang seperti berita hoax, peneroran, situs-situs porno yang banyak muncul saat membuka internet tanpa pengawasan membuka mesin pencarian seperti Google, Instagram, Youtube, dan lainnya yang hanya dengan satu klik dapat merusak jaringan otak pada remaja karena situs buruk tersebut, belum lagi bahaya yang lain seperti kasus penipuan yang banyak terjadi sekarang ini, bahkan ada yang menjadi korban jutaan rupiah.

Oleh sebab itu, dari problematika tersebut peneliti tertarik untuk melakukan penelitian tentang Nilai Moral Bagi Kalangan Muda Dalam Mempergunakan Internet, peneliti ingin mengkaji seberapa penting moral kalangan anak muda dalam menggunakan internet seperti Game online, Instagram, Youtube dan lain-lain. Apakah dengan adanya kesadaran atau memiliki moral anak- 
anak muda bisa lebih bijak dalam menggunakan internet. Mengingat pentingnya memiliki nilai moral dalam menggunakan internet khususnya untuk kalangan anak muda.

\section{METODE PENELITIAN}

Metode penelitian yang digunakan oleh peneliti dalam penelitian jurnal ilmiah ini merupakan metode penelitian kualitatif. Bogdan dan Taylor (Moleong, 2007: 4) berpendapat bahwa metodologi kualitas sebagai proses penelitian yang menghasilkan data deskriptif tentang orang-orang dan perilaku mereka dalam bentuk bahasa tertulis atau lisan. Pendekatan ini menitikberatkan pada latar belakang seseorang secara keseluruhan. Oleh karena itu, dalam hal ini tidak diperbolehkan mengisolasi individu atau organisasi berdasarkan variabel atau organisasi. Hipotesis, tetapi harus dilihat sebagai bagian dari keseluruhan.

Studi kasus diartikan sebagai metode atau strategi dalam penelitian untuk mengungkap kasus tertentu. Penelitian studi kasus memusatkan perhatian pada satu objek tertentu yang diangkat sebagai sebuah kasus untuk dikaji secara mendalam sehingga mampu memecahkan realitas di balik fenomena. Data studi kasus dapat diperoleh dari semua pihak yang bersangkutan, baik melalui wawancara, observasi, partisipasi, dan dokumentasi. Data yang diperoleh dari berbagai cara itu pada dasarya adalah sebagai pelengkap.

Menururt Lincoln dan Guba (Dedy Mulyana, 2004: 201) penggunaan studi kasus sebagai suatu metode penelitian kualitatif memiliki beberapa keuntungan, yaitu; 1) Studi kasus dapat menyajikan pandangan dari subjek yang diteliti, (2) Studi kasus menyajikan uraian yang menyeluruh yang mirip dengan apa yang dialami pembaca kehidupan sehari-hari. (3) Studi kasus merupakan sarana efektif untuk menunjukkan hubungan antara peneliti dan responden. (4) Studi kasus dapat memberikan uraian yang mendalam yang diperlukan bagi penilaian atau transferabilitas.

Pada dasarnya penelitian dengan jenis studi kasus bertujuan untuk mengetahui tentang sesuatu hal secara mendalam. Maka dalam penelitian ini, peneliti akan menggunakan metode studi kasus untuk mengungkap tentang permasalahan yang terjadi yaitu kemorosotan moral dikalangan anak muda akibat penggunaan internet, untuk mengungkapkan sebarapa penting moral kaum muda dalam mempergunakan internet secara bijak.

Subjek penelitian dalam penelitian kualitatif ini terdiri atas tiga elemen yaitu: tempat (place), pelaku (actors), dan aktivitas (activity) yang berintraksi secara sinergis, yang oleh Spraddley di namakan "Social situation" atau situasi sosial. Subjek adalah responden dan informan yang akan dimintai keterangan. Subjek dalam penelitian kulitatif ini terdiri atas masyarakat, orang tua dan khususnya anak muda sebagai informan. Mengingat subjek yang baik adalah subjek yang terlibat aktif, cukup mengetahui, memahami, atau berkepentingan dengan aktivitas yang akan diteliti, serta memiliki waktu untuk memberikan informasi secara benar. Subjek penelitian akan meneliti 3 orang subjek yang akan diwawancara yaitu dari kalangan orang tua, remaja, dan masyarakat sekitar tempat tinggal peneliti yaitu di daerah Majalaya.

Teknik pengambilan data yang digunakan oleh penulis adalah purposive samling. Purposive sampling merupakan salah satu teknik pengambilan sampel yang sering di gunakan dalam penelitian. Secara bahasa purposive berarti sengaja. Jadi, purposive sampling adalah teknik pengambilan sampel secara sengaja. Maksudnya, peneliti menentukan sendiri sampel yang diambil tidak secara acak. Tapi ditentukan sendiri oleh peneliti. Teknik ini didasarkan pada ciri atau sifat tertentu yang diperkirakan yang mempunyai sangkut paut dengan ciri-ciri atau sifat-sifat yang ada dalam populasi dijadikan kunci untuk sampel. Dalam penelitian ini, masyarakat, orang tua, dan remaja menjadi sampel yang dapat memberikan informasi yang terkait dengan dampak pengguna internet. Sehingga apabila dicari informasi terkait dengan penelitian tersebut kepada sampel lain, maka tidak diperoleh informasi yang baru karena informasi atau data-data telah diperoleh sudah mencukupi penelitian penulis. 


\section{PEMBAHASAN DAN HASIL}

Nilai Moral Anak Muda dalam Mempergunakan Internet, Pola prilaku anak muda dalam menggunakan internet cenderung memberikan informasi pribadi mereka pada media digital, sejumlah besar anak muda di Indonesia terekspos konten pornografi, secara sengaja, ataupun tidak sengaja, minimnya pengawasan orang tua terhadap aktivitas digital yang dilakukan oleh anak juga mendorong terjadi "penyimpangan" penggunaan internet, prilaku perundungan (bully), dan mudahnya mengeluarkan kata-kata makian pada laman media sosial di internet, menunjukkan telah terjadi degradasi moral terhadap anak muda, penggunaan media digital dan internet juga mendorong timbulnya kejahatan cyber.

Pew Research Center mewawancarai lebih dari 36.000 orang di 32 negara berkembang dalam penelitian. Mereka diajukan pertanyaan terkait pemakaian Internet oleh individu. Mayoritas pengguna, sebanyak 64 persen berkata Internet memberi pengaruh positif untuk pendidikan. Namun, sebanyak 42 persen berpikir Internet buruk untuk moralitas, hanya 29 persen yang mengatakan Internet memberi pengaruh baik pada moralitas. (

Untuk menjelaskan hal ini dilaksanakan diskusi yang berkaitan dengan hal tersebut, dengan mengemukakan beberapa pertanyaan yang meliputi:

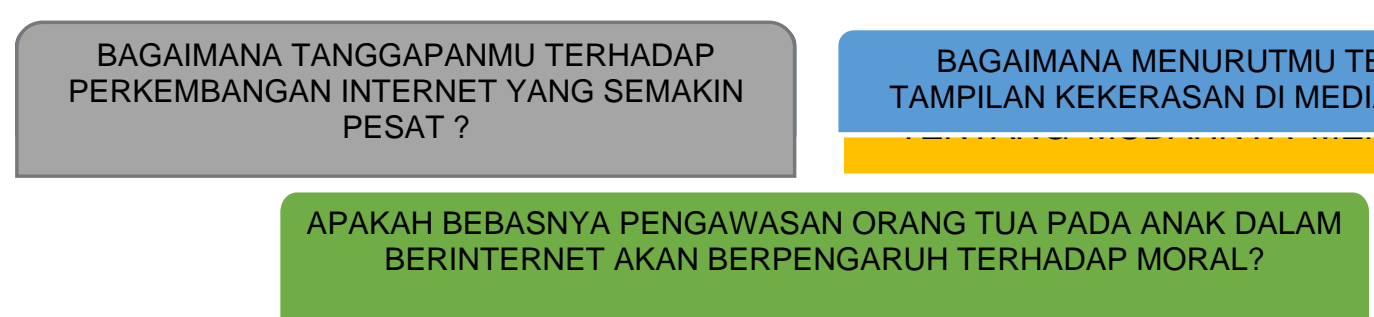

Setelah melakukan observasi dan wawancara kepada masyarakat di Desa Majalaya terkhusunya anak muda, penulis akan merangkum dan membahas secara sederhana. Hasil wawancara tersebut akan dikaitkan dengan permasalahan yang kerap terjadi dari kurang bijaknya dalam penggunaan internet. Berdasarkan hasil wawancara penulis ada 3 aplikasi yang menggunakan jaringan internet yang sering digunakan yaitu, youtube, istagram, dan game online. Youtube adalah media yang kini sedang booming dikalangan remaja khususnya di Desa Majalaya media ini menjadi wadah para anak muda untuk berkreasi secara bebas tanpa perlu mengeluarkan biaya yang besar. Musik, film, dan berita adalah konten yang paling banyak diakses maupun diunggah di youtube. Dari observasi penulis dilapangan anak muda mengenal yang namanya youtube meskipun hanya sesekali menggunkannya bukan hal yang asing lagi. Hal ini juga dibuktikan berdasarkan wawancara penulis dengan remaja di Desa Majalaya. Wawancara penulis dengan remaja di Desa Majalaya mengatakan bahwa:

"Iya saya suka buka youtube karena di youtube banyak sekali tontonan-tontonan yang menggiurkan sehingga kita tertarik untuk menontonnya banyak berita-berita, musik, film, vidio-vidio lucu. Mau cari tentang pendidikan juga ada di youtube" Youtube sering digunakan oleh remaja di Desa Majalaya yang mana youtube ini banyak sekali hal-hal yang menggiurkan di dalamnya, sehingga membuat para penggunanya sering menggunakannya.

Selain itu juga, kehadiran Instagram dikalangan remaja menjadi sebuah fenomena yang menarik. Berdasarkan wawancara dengan remaja di Desa Majalaya. Wawancara penulis dengan dengan remaja di Desa Majalaya mengatakan bahwa:

"lya benar saya punya instagram, di istagram saya sering memasukkan foto dan video yang saya suka. Di istagram juga bisa berkomunikasi seperti komen-komenan sama temen dan bisa menumpahkan emosi yang dirasakan di instagram."

Wawancara diatas dapat penulis simpulkan bahwa remaja di Desa Majalaya ini sudah mengengenal instagram yang mana instagram dapat menyimpan foto dan video yang di sukainya. Intagram juga sebagai tempat berintraksi dengan orang lain dan menumpahkan segala emosi yang di rasakan. dengan jaringan internet yang dimiliki.

Adapun Game online biasanya banyak dimainkan oleh remaja. Game online yakni game yang dimainkan oleh multi pemain yang dapat dimainkan yang memanfaatkan jaringan komputer 
internet maupun Smarphone, sebagai medianya. Permainan yang dapat diakses lansung melalui sistem yang disediakan sebagai tanbahan layanan dari perusahaan penyedia jasa online. Banyak jenis permainan online, dari mulai permainan sederhana berbasis teks sampai permainan yang menggunakan grafik konfleks dan membentuk dunia virtual yang dapat dimainkan oleh banyak pemain. Berdasarkan yang penulis lihat dilapangan bahwa remaja di Desa Majalaya sangat menggemari Game Online yang dapat berpengaruh terhadap kehidupan remaja di Desa Majalaya.

Wawancara dengan remaja yang sudah di katakan kecanduan bermain game online di Desa Majalaya mengatakan bahwa:

"Saya sangat suka main game online saya selalu main kalau sudah main lupa waktu saya sering main game Mobile Legends, Garena Free fire, PUBG Mobile Lite. Game ini lah yang sering saya mainkan sama temen-temen bahkan sampai pernah lupa waktu"

Penjelasan di atas mengenai game online dapat disimpulkan bahwa game online sangat digemari oleh remaja di Desa Majalaya yang mana game yang di maksud yakni Mobile Laagends, Grene Free fire dan PUBG Mobile Lite yang banyak digunakan di Desa Majalaya. Dari wawancara di atas mengatakan bahwah permainan ini sangat menghibur di atara permainnan yang lain dan menimbulkan rasa kecanduan terhadap game online. Maka dari itu, penulis menyimpulkan bahwa anak muda di Desa Majalaya memang sudah memahami teknologi digital dan banyak yang sudah bisa mengakses internet. Aplikasi yang sering digunakan untuk menunjang kepuasan, informasi, eksistensi dan juga hiburan.

Berkaitan dengan anak muda yang sudah memahami penggunaan internet tentunya, nilai moral juga harus dipahami oleha anak muda. Menurut Chaplin dalam (Sutarjo Adisusilo:2013) Moral merupakan nilai yang berlaku dalam suatu lingkungan sosial dan mengatur tingkah laku seseorang, yang artinya moral menjadi tolak ukur yang dipakai oleh masyarakat untuk menentukan baik buruknya tindakan manusia sebagai manusia. Berkenaan dengan hal itu, anak muda yang menggunakan internet itu harus memiliki nilai moral yang baik agar tidak terjerumus dengan dampak negatif dari internet yang digunakan.

Setelah mengobservasi dan melakukan wawancara ternyata masih banyak anak muda yang belum bisa melakukan batasan diri dari menggunakan media sosial, selain itu juga, banyak anak muda yang kedapatan membuka situs-situs yang berbahaya dan bisa merusak moral bangsa yakni situs pornografi dan platform media sosial. Kemudahan teknologi internet telah memungkinkan disalahgunakan oleh beberapa kalangan yang kurang menjunjung etika dan moralitas dengan menciptakan situs-situs porno yang mengeksploitasi gambar atau video porno (Oetomo, 2002: 65). Oleh karena itu, perlu pengawasan yang ketat bagi remaja jika ingin mengakses situs-situs dari internet karena bisa mempengaruhi dan merusak psikologi remaja.

Seperti wawancara penulis lakukan dengan orang dewasa di Desa Majalaya yang menyatakan bahwa:

"Akses pornografi itu sudah menjadi bisnis dan masih banyak website yang sebenarnya ilegal pemerintah masih membuka website tersebut, Saya tidak pernah membukanya namun teman Saya sering bercerita akan hal itu. Lebih parahnya ada website yang memang untuk edukasi akan tetapi iklannya tidak senonoh hal itu bisa berakibat fatal apabila ada seorang anak yang membuka website tersebut, terlebih lagi penggunaan platform instagram, youtube dan juga game online yang mudah diakses dan itu akan sulit terkontrol bahkan bisa moral anak muda bisa merosot bahkan bisa menyebabkan kecanduan dan gangguan psikis lainnya jika itu digunakan secara tidak bijak atau berlebihan."

Selain itu juga, di internet banyak konflik yang terjadi baik itu unsur kesengajaan ataupun tidak sengaja. Terlihat dari penelusuran yang penulis lakukan banyak sekali penyebaran berita hoax, perundungan online, ujaran kebencian, bahkan pertengkaran antara influencer atau artisartis yang kerap terjadi. Apakah itu sudah mendidik? Tentunya tidak, itu hanya untuk kepuasan beberapa pihak saja, sebagai penonton dan yang suka berselancar di internet itu adalah hal yang tidak baik. Ini adalah salah satu hal yang perlu diperhatikan oleh masyarakat terutama anak muda. Nilai moral itu sangat penting untuk diterapkan agar senantiasa terhindar dari pengaruh buruk di internet. Sebagaimana penulis melakukan wawancara dengan Mahasiswa yang berdomisili di Majalaya menyatakan: 
"Orang lebih gampang buat ngebully dan provokasi. Seperti kebebasan dalam mengeluarkan pendapat yang sering disalahgunakan oleh penggunanya, banyak netizen yang memberikan kritikan yang tidak membangun bahkan cenderung menghujat sesama penggunanya, hal itu sering ditemukan di sosial media. Banyak banget berita hoax, contohnya kali ini sedang pandemi global, banyak informasi hoax yang bisa menghasut beberapa orang dan akhirnya dapat menyebabkan konflik. Terus kadang orang-orang yang ga bijak pakai internet suka komentar seenaknya, apalagi kalo komentarnya pakai kata ${ }^{2}$ kasar, kadang ada juga yang playing victim, dan masi banyak lagi."

Berdasarkan wawancara, lantas bagaiaman agar anak muda bisa terhindar dari perilakuperilaku tersebut? Tentunya lingkungan sosial akan membentuk prilaku seseorang karena lingkungan sosial memberikan pengalaman prilaku dan sikap sehingga anak muda dapat menilai mana prilaku yang baik atau buruk dan mana yang boleh dan tidak boleh. Penyimpangan prilaku merupakan perbuatan yang bertentangan dengan norma-norma yang berlaku di masyarakat. Menurut Yunisca Nurmalisa (2016) menyatakan, apabila dalam masyarakat tidak tampak lagi keunggulan moral dimana sopan santun hidup kurang terpelihara, agama dan nilai/norma tidak terlihat lagi serta penyimpangan prilaku nilai sering terjadi, berarti dapat dika takan telah merosotnya moral masyarakat tersebut.

Peran Orang Tua dan Orang Dewasa untuk Mendidik dan Memberikan Pendidikan Moral kepada Anak Muda, Penggunaan internet boleh di tekankan kepada pembelajaran yang melibatkan ketercapaian kepada informasi. Internet nengandung kumpulan data dan informasi yang banyak berkaitan dengan berbagai topik dan cara berkomunikasi melalui kemudahankemudahan yang tersedia. Internet memang sangat membatu seseorang untuk mencari informasi dan pengetahuan namun tidak sedikit orang yang keliru untuk membedakan yang mana berdampak positif dan yang mana negatif. Maka dari itu, nilai moral yang harus ditanamkan anak muda dalam menggunakan internet itu harus diperhatikan dan sebagai orang tua harus menjadi peran.

Peran yang harus dimiliki orang tua adalah mengwasi anak muda dalam menggunakan internet terkhususnya untuk anak muda yang berumur dibawah 17 tahun yang masih bisa rentan untuk meniru dan masih memiliki pola pikir yang berlum terlalu matang. Berikut adalah respon orang tua di Desa Majalaya, Internet adalah suatu kebutuhan yang di butuhkan bagi para penggunanya. Dalam kesaharian kita selalu menggunakan internet namun, selain dampak positif internet juga dapat menimbulkan dampak buruk bagi penggunanya khususnya pada anak muda. Orang tua anak muda yang diwawancara mengakui bahwa anaknya kerap sekali buka internet. Namun orang tuanya hanya menginginkan anaknya membuka internet seperlunya saja jangan sering membuka internet jika tidak penting seperti main game online, instagram dan nonton youtube yang tidak penting hal ini pasti sangat di sayangkan waktu yang seharusnya di gunakan untuk suatu hal yang lebih bermanfaat terbuang sia-sia hanya dengan kegiatan yang tidak begitu penting.

Penjelasan dari salah satu orang tua dari anak muda, anaknya sudah tidak seperti sebelumnya, sebelum mengenal internet anaknya masih semangat belajar setelah mengenal internet semangat belajarnya kurang apa lagi setelah mengenal yang namanya game online, bahkan ada prilaku-prilaku yang tidak terpuji dan mengganggu orang lain.

Berkaitan dengan hal tersebut perkembangan moral (moral development) berhubungan dengan peraturan dan nilai-nilai mengenai suatu hal yang harus dilakukan seseorang dalam interaksinya dengan orang lain. Anak-anak ketika dilahirkan tidak memiliki moral, tetapi dalam dirinya terdapat potensi yang siap untuk dikembangkan. Karena itu, melalui pengalamannya dalam berinteraksi dengan orang lain seperti orang tua, saudara atau teman sebayanya anak belajar memahami tentang perilaku mana yang baik, yang boleh dikerjakan dan tingkah laku buruk, yang tidak boleh dikerjakan. Jadi, moral berkaitan dengan kemampuan seseorang untuk membedakan antara perbuatan yang benar dan yang salah. Moral juga mendasari dan mengendalikan seseorang dalam bersikap dan bertingkah laku.

Berdasarkan berdasarkan hasil observasi dan wawancara ada beberapa perilaku remaja yang tidak wajar hal ini menyebabkan timbulnya rasa khawatir dari orang tua. Agar anak muda sadar akan pentingnya nilai moral dalam penggunaan internet. Haruslah ada pengawasan dari orang sekitar. Menanamkan dasar-dasar keimanan, keperibadian, budi pekerti yang terpuji dan 
kebiasaan ibadah yang sesuai kemampuan remaja sehingga menjadi suatu motivasi anak muda yang bertinggkahlaku adalah hal yang mungkin diharuskan dalam menanamkan nilai-nilai agama sesuai yang dikatakan selaku toko agama di Desa Majalaya mengatakan bahwa dengan adanya penerapan nila-niali agama anak muda akan memiliki motivasi dan dorongan-dorongan itu perlu untuk meningkatkan keimanan dan itu adalah tanggung jawab dari kedua orang tuanya yang mana orang tua harus mendidik anaknya bagaimana membangkitkan keimanan dan memperbaiki aklah dari anak tersebut.

Kebanyakan anak muda sudah terjebak dengan hal-hal yang semu dan instan dalam peroses kehidupannya, meniru tanpa ada nilai kesadaran yang kuat yang telah tertanamkan kepadanya menjalankan pembelajaran baik di lembaga maupun diluar. Oleh karna itu hal tersebut perlu diwicanakan dan dilakukan dengan terencana dengan demikian, nilai-nilai kesadaran tersebut merupakan dasar yang harus ditanamkan kepada remaja Hal ini sesuai dengan wawancara masyarakat di Desa Majalaya.

"Tentunya sebagai orang tua sudah menjadi kewajiban untuk memantau perkembangan anaknya seperti yang kita ketahui anak muda ini memiki ego yang tinggi sehingga sering kehilangan kontrol maka nilai-nilai kesadaran tersebut merupakan dasar yang harus ditanamkan kepada anak muda." Beberapa wawancara dan uraian di atas menunjukan nilai moral anak muda dalam mempergunakan internet itu sangatlah penting dan apabila ada anak muda yang sudah terkena dampak negatif dari internet serta moral nya sudah merosot maka dapat ditannggulangi dengan cara menanamkan nilai-nilai agama pada anak muda, meningkatakan kesadaran anak muda, kemudian meningkatan kedisiplinan pada anak muda. Berdasarkan uraian di atas penulis bisa menyimpulkan bahwa agar anak muda memiliki nilai moral dalam mempergunakan internet tentunya selain harus memiliki kesadaran dari dalam diri anak muda itu sendiri, peran orang tua sebagai pengawas untuk anak muda itu sangat dibutuhkan, agar anak muda itu tidak terjerumus kepada hal-hal yang buruk yang ada di internet.

\section{KESIMPULAN}

Berdasarkan dari hasil penelitian Nilai Moral Anak Muda dalam Mempergunakan Internet, maka dapat ditarik beberapa kesimpulan. Penggunaan internet melalui youtube, instagram, game online, situs ini yang paling sering digunakan oleh remaja di Desa Majalaya yaitu instagram dan game online. Dampak dari penggunaan internet dapat bersifat positif maupun negatif di ataranya, yaitu menambah wawasan dan pengetahuan, menjadikan media komunikasi, memudahkan mencari lowongan pekerjaan, internet sebagai sarana belajar bisnis, internet dapat memperbanyak teman dari usia remaja samapai yang dewasa, Sarana pembelajaran.

Dampak negatif menggunakan internet yaitu dapat memudahkan menemukan pornografi, dapat menimbulkan komplik sosial, kurangnya bersosalisasi dengan lingkungan, tidak peduli dengan teman sekitar, menghamburkan uang, mengganggu kesehatan, berkurangnya waktu beajar, tersebarnya data peribadi, menimbulkan rasa kecanduan.

Respon orang tua/masyarakat menganggap bahwa anak muda diaggap belum bisa menggunakan internet dengan bijak dan nilai moral yang dimiliki harus diperbaiki. Selain itu juga, orang tua remaja menginginkan anaknya menggunakan internet apabila bermanfaat bagi anaknya bukan menghabiskan waktu dengan berjam-jam dengan hal yang tidak penting sehingga dapat menimbulkan dampak yang negatif bagi anaknya. Orang tua yang perduli dengan perkembangan anaknya akan membatasi penggunaan internet pada anaknya orang tua yang kurang perduli maka tidak begitu membatasi.

Upaya penanggulangan perilaku negatif atau amoral terhadap penggunaan internet pada anak muda. Agar nilai moral senantiasa digunakan anak muda dalam menggunakan interniet ada beberapa yang bisa diperhatikan dan diterapkan yakni, Menanamkan nilai-nilai agama, Meningkatkan kesadaran anak muda, dan Peran meningkatkan kedisiplinan

\section{Referensi}

Panji, Aditya. "Negara Berkembang Berpikir Internet Buruk Untuk Moral." Teknologi, www.cnnindonesia.com/teknologi/20150320101507-185-40505/negara-berkembang-berpikir-

internet-buruk-untuk-moral. Accessed 8 July 2021. 
Basyari, I. (2019). Sebagian Kasus Kenakalan Remaja Dipicu Media Sosial. Kompas Media Nusantara. https://www.kompas.id/baca/nusantara/2019/12/20/sebagian-kasus-kenakalan-remaja-dipicu-mediasosial/

Fredik Melkias Boiliu, Kaleb Samalinggai, Devi Wahyu Setiawati. (2020). "Peran Pendidikan Agama Kristen Di Era Digital Sebagai Upaya Mengatasi Penggunaan Gadget Yang Berlebihan Pada Anak Dalam Keluarga Di Era Disrupsi 4.0", Jurnal DIDACGE, 1.1 25-28

Hartley, John. (2010). Communication, Cultural and Media Studies. Yogyakarta: Jalasutra.

Kartila,I. (2013). Pornografi di Kalangan Pelajar, Mengerikan. Antarajatim. http://www.antarajatim.com/lihat/b erita/121616/pornografi-di-kalangan-pelajar-mengerikan/

Ma'rufah, Nurbaiti. Rahmat Khairul, Hayatul. Widana Ketut Kerta, I Dewa. (2020). Degradasi Moral Sebagai Dampak Kejahatan Siber Pada Generasi Millenial Di Indonesia. Jurnal IImu Pengetahuan Sosial, Vol 7 No 1 Tahun $2020191-201$

Meleong, Lexy. Metodologi Penelitian Kualitatif, Bandung: Remaja Rosadakarya, 1996

Mulyana, Dedy. (2004). Metodologi Penelitian Kualitatif (Paradigma baru ilmu komunikasi dan ilmu sosial lainnya). Remaja Rosdakarya

Nurfitriana, Ika (2021) Nilai-Nilai Moral dalam Animasi Kartun Nussa serta Relevansinya pada Buku Ajar Akidah Akhlak di Madrasah Ibtidaiyah. Undergraduate (S1) thesis, IAIN Ponorogo.

Nurjanah, S. (2018). Perkembangan Nilai Agama Dan Moral (Sttpa Tercapai). Jurnal Paramurobi, 1(1).

Nurmalisa, Yunisca. "Peran Lembaga Sosial Terhadap Pembinaan Moral Remaja Di Sekolah Menengah Atas." Jurnal IImiah Pendidikan Pancasila Dan Kewarganegaraan, vol. 1, no. 1, 26 June 2016, pp. 64-71,

Oetomo, Budi Sutedjo Dharma.(2002) Pengantar Teknologi Informasi Internet : Konsep dan Aplikasi. Yogyakarta. Andi

P.A, Ana. Nurmalita, Anike. (2014) Teknologi Komunikasi Dan Perilaku Remaja. Jurnal Analisa Sosiologi, 3(1): $91-111$

Prendi Budi Kusuma, \& Sri Sedar Marhaeni. (2020). Pengaruh Penggunaan Internet Terhadap Moral Siswa Man 3 Banyuwangi. Jurnal Pendidikan Pancasila Dan Kewarganegaraan, 5(1), 15-19. Retrieved from https://ejournal.unibabwi.ac.id/index.php/jppkn/article/view/986

Ridho, A. A. (2020) Peran Keluarga dalam Meningkatkan Nilai Moral Anak Usia Dini. Pedagogi: Jurnal IImu Pendidikan Vol 20 No 1, 29-32

Rusnali, A. A. (2020). Media Sosial dan Dekadensi Moral Generasi Muda. Connected: Jurnal IImu Komunikasi, 1(1), 29-37. Retrieved from http://jpii.upri.ac.id/index.php/connected/article/view/5

Santrook, JW. (2012). Life-Span Development: Perkembangan Masa Hidup. Jakarta: Erlangga.

Zuriah, N. (2007). Pendidikan Moral dan Budi Pekerti dalam Perspektif Perubahan Bumi Aksara 